GEOGRAFIE • ROK 2015 • ČÍSLO 2 • ROČNÍK 120

\author{
ANNELI KÄHRIK, JAKUB NOVÁK, JANA TEMELOVÁ, \\ KATI KADARIK, TIIT TAMMARU
}

\title{
PATTERNS AND DRIVERS OF INNER CITY SOCIAL DIFFERENTIATION IN PRAGUE AND TALLINN
}

\begin{abstract}
KÄHRIK, A., NOVÁK, J., TEMELOVÁ, J., KADARIK, K., TAMMARU, T. (2015): Patterns and Drivers of Inner City Social Differentiation in Prague and Tallinn. Geografie, 120, No. 2, pp. 275-295. - During the socialist era, inner residential areas of Eastern European cities were left to decay both physically and socially, and became mostly occupied by elderly inhabitants. Drawing on 2007-2011 EU-SILC data, we have analysed processes of socio-spatial differentiation in the inner cities of Prague and Tallinn during the post-socialist era, and indicate the household-level drivers of such differentiation. We found a high preference for inner city living among young people and childless households, but also the persisting patterns of elderly population in some inner city sub-areas. A weak correlation between household socio-economic status and place of residence in the inner city, however, suggests that inner cities continued to be socially mixed in the late 2000 s, although differences existed in this regard between sub-areas and between the two studied cities. To a large extent, such differentiation relates to the roots found within socialist and pre-socialist legacies, but it also contains new post-socialist features, such as those created by different social and housing policies applied during the post-socialist reforms.

KEY WORDS: Inner city - residential differentiation - EU-SILC - logistic regression Prague - Tallinn.
\end{abstract}

This research was supported by Grant No. 332265 of the Marie Curie Intra European Fellowship within the $7^{\text {th }}$ European Community Framework Programme; Grant No IUT2-17 of the Ministry of Education and Science Estonia; and Grant No GA14-00393S of the Czech Science Foundation.

\section{Introduction}

Facilitated by political and economic reforms launched in the 1990s, the step-by-step renewal of inner city zones has characterised Eastern European cities over the last two decades (i.e., Feldman 2000; Haase et al, eds. 2011; Kovács 2009; Sýkora 2005; Temelová 2007). These urban zones - namely the residential areas located in-between the central business district and outer urban zones, usually characterised by the existence of historical pre-socialist urban layers, - were typically left to physical decay under the socialist regimes, as the focus of housing construction shifted to building high-rise housing estates in outer urban zones (Smith 1996, Enyedi 1998). Often, the elderly and lower social status groups had been over-represented in inner cities, while younger more educated groups had moved to new housing estates (Szelényi 1996; Kährik, Tammaru 2010; Temelová et al. 2011). Only the most prestigious 
inner city historical quarters as well as newer infills retained a higher status and prestige throughout the socialist era. Nevertheless, differences in presocialist physical layers, to the extent of the newly built housing, as well as in population composition and housing policies, contributed to variations in social patterns across cities in Eastern Europe (e.g., Smith 1996, Marcinćzak et al. 2015).

The limited evidence suggests that the physical renewal of post-socialist inner cities has been coupled with upward social change but residential dynamics tend to have a diverse character throughout the cities, depending on these aforementioned physical and social contextual differences and applied institutional reforms (e.g., Marcinćzak et al. 2015). Many authors agree that residential mobility, demographic and in-situ status changes have led to up and downgrading processes of social status taking place in close proximity (Bernt, Holm 2005; Golubchikov, Badyina, Makhrova 2014; Haase et al., eds. 2011; Kovács 2009; Temelová, Dvořáková 2012; Temelová, Novák 2011). The majority of studies so far have been restricted to specific urban neighbourhoods and not mapped the overall changes in Eastern European inner cities, nor have they shed much qualitative insights on inner city social transformations (e.g., Kovács 2009; Haase et al., eds. 2011; Kährik et al. 2015). The quantitative accounts that have targeted the social change of inner city areas, by comparing with international examples, have been extremely rare and have not included income indicator (e.g., Marcinćzak et al. 2015, Tammaru et al. 2015b).

With this paper, we aim to expand the existing knowledge on inner city change, by examining inner city socio-demographic differentiation in selected Eastern European cities from a demand-side perspective and focusing on the characteristics of the inner city population in the late 2000 s, i.e., two decades after the beginning of the systemic socio-economic transformations in this region. More specifically, we seek answers to the following two questions: (1) What demographic and socioeconomic features characterise the selected inner city residents compared to those in the outer parts of the cities?, and (2) Is there evidence in these inner cities of differentiation by population groups across inner city sub-districts and housing submarkets? Empirical insights into these research questions would help to clarify what directions and to what extent the overall social and demographic shifts taking place in Eastern European inner cities change the intra-urban geography of post-socialist cities, as well as build up knowledge on spatial patterns of socio-demographic composition within inner cities on a sub-area level.

By including two different cities - Prague in Czechia and Tallinn in Estonia - in the study, it allows us to shed light on generic changes and variations in these patterns across Eastern Europe. The cross-country perspective was applied to broaden the empirical scope of analyses, as well as to increase understanding on the impact of contextual factors on socio-spatial outcomes. While sharing many common features and legacies of the communist past, as well as the practice of applying quick political and economic reforms in transition from regulated to market economy, Prague and Tallinn differ in the degree of market regulations during the transition period, as well as the extent of social inequalities in societies (Marcinćzak et al. 2015). As has been pointed out by many authors, different regulatory socio-political regimes and institutional 
settings tend to influence urban structures and residential outcomes most directly (e.g., Kazepov, ed. 2004; Teernstra, van Gent 2012).

We proceed, first, with a theoretical insight into the inner city transformation in Eastern Europe during the post-socialist era. This theoretical introduction is followed by contextual information on the two selected case study cities, and hypotheses for the analyses. Thereafter, the methodological approach to the study is presented and, finally, conclusions and discussion of the empirical results will sum up the study.

\section{Inner city dynamics in Eastern European cities during the post-socialist era}

Gentrification studies carried out in Western cities have indicated that inner cities, including many of the former industrial areas, have been undergoing physical and social upgrade since the 1960s. The rejuvenation processes and social upgrade (lower social status groups being displaced by higher social status groups) have often been led by urban policy initiatives, as city governments have been seeking to stop the continuous downgrading of city centres. The in-migration of higher social status groups has been described in the form of successive waves - artists and students are often the first-movers to dilapidated inner urban areas, while the subsequent waves increasingly consist of wealthier, middle-class households, - the groups that transform inner cities into affluent neighbourhoods (e.g., Zukin 1982, Ley 1996); certain areas have even become attractive to the super-rich, as exemplified by parts of inner city New York and London (Butler, Lees 2006).

Despite the dominance of the gentrification discourse in explaining changing inner city residential composition, a growing number of authors have pointed out a variety of processes reshaping inner cities (e.g., Beauregard 1990; van Criekingen, Decroly 2003; Haase et al. 2010; Teernstra, van Gent 2012); according to these authors, inner cities represent a mixture of social groups and areas. Young adults in a transitional family and/or professional stage, students, artists, middle-class families, ethnic minorities and long-term residents have all been identified as active in the processes of inner city regeneration and/or re-urbanisation (see also Bostic, Martin 2003; Karsten 2003; Smith, Holt 2007; Boterman, Karsten, Musterd 2010). Gentrification should therefore be seen as one of several processes of neighbourhood dynamics (e.g., rejuvenation without social status change, studentification, reurbanisation, in-situ changes, stability and downgrading trends) that reshapes inner cities.

In contrast to the extensive and long-term research on neighbourhood change in Western cities, not much attention has been paid to the transformation processes in post-socialist inner cities. Sýkora and Bouzarovski (2012) point out that socio-spatial change in Eastern European cities follows changes on institutional level and socio-economic structures. Structural shifts in the housing and economic system, particularly the restitution and privatisation of housing stock, together with rent reforms in restituted flats (Hegedüs, Lux, Teller, eds. 2013; Lux, Kährik, Sunega 2012), have created the preconditions for sociospatial changes in Eastern European cities. While the dominant public policy 
approach to urban development has been of the neoliberal kind, where physical renewal largely depends on the initiative of private bodies and their selective investments (Badyina, Golubchikov 2005; Feldman 2000; Temelová 2007), in a few examples local governance structures have facilitated the formation of strategic public-private partnerships (Földi 2008; Kovács 2009). The transition has not taken place in a linear way across the region; political, social and spatial changes marked significant differences between countries and cities (Hegedüs, Lux, Teller, eds. 2013; Tammaru et al. 2015b). Compared to Western European cities, the lack of clear public policy on inner city change characterises cities in Eastern Europe.

Eastern European inner city areas have experienced selective location-dependent social upgrade; authors have pointed to the simultaneous presence of lower social status residents, often elderly, and higher social status newcomers who share the same neighbourhoods or live in adjacent areas (Kährik et al. 2015 , Kovács 2009). Social upgrade tends to radiate gradually from better locations and higher prestige inner city areas to their surroundings (Tammaru et al. 2015a). Inner city neighbourhoods predominantly tend to attract households at the younger non-family stage - so called "transitory urbanites", i.e. people in their 20 s or early 30 s who are highly educated early stage professionals or students and often sharing rental accommodations (Buzar et al. 2007; Haase et al., eds. 2011; Haase, Grossmann, Steinführer 2012; Steinführer, Haase 2007). Haase et al. (2011) characterise many of the newcomers by their cultural rather than economic capital. Taking advantage of the infrastructure and easy access to workplaces and leisure-time opportunities tends to be an important motive underlying such residential choices; however, this group usually regards their inner city residence as temporary (ibid. 2011). Inner city housing stock with many rental and smaller-scale apartments, including substandard apartments, often provide suitable conditions for those residents (e.g., Kährik et al. 2015). The transitory character of new young inner city residents has also been identified in Western European cities and has re-ignited the debate on the fragility of the re-urbanisation process (Seo 2002; van Criekingen, Decroly 2003).

The groups living in the inner cities of Eastern European countries tend to exhibit a great socio-economic heterogeneity, mixture of household types, living and housing arrangements, and residential attitudes. The role of "sedentary" population groups, such as elderly long-term residents, should also not be underestimated (Temelová, Dvořáková 2012); whereas the study by Kährik et al. (2015) also points to the influx of families with children who are committed to their place of residence and result in a mix of socio-economic resources and age groups living in the same or adjacent neighbourhoods. While the historic quarters with unique milieu, or newly built residential infills, attract higher income movers, substandard apartments are continuously destinations for residents with lower socio-economic resources. "Hybrid spaces" might emerge when different socio-economic, demographic and lifestyle groups mix together in the city in increasingly diverse ways as socialist legacy and new capitalist forces interact (Golubchikov, Badyina, Makhrova 2014).

Previous studies lead us to formulate the following three hypotheses: first, that, as in the West, young (non-family) people are over-represented in the inner cities of Prague and Tallinn; second, because Tallinn has been exposed to a 
greater degree of social inequality than Prague, we expect greater differences between inner city inhabitants and the remaining city dwellers in Tallinn compared with Prague; third, for the same reason, we hypothesise that differentiation across the inner city sub-areas is greater in Tallinn than in Prague.

\section{Contexts of the case study cities}

Estonia was part of the Soviet Union from 1944 until its independence was restored in 1991, while democracy was re-established in the Czechia in 1989 after the collapse of the communist rule. The majority of the systemic reforms were completed in both countries by the end of the 1990s. Despite the fast economic reforms in Czechia, the country retained a high degree of social equality (Večerník 1996). The egalitarian elements related to the relatively generous social benefit system, rent regulations for restituted houses, and relatively slow and regulated housing privatisation in comparison to other former socialist countries (Hegedüs, Lux, Teller, eds. 2013). Like in Tallinn, the majority of pre-WWII tenement houses were returned to their previous owners but, unlike in Tallinn, they have been subject to long-lasting rent regulation (that lasted until 2012), keeping housing rents low and thereby affordable to older and less affluent people.

Estonia represents an example of a clear-cut and radical shift from socialism to neoliberal capitalism (World Bank 2002). Social inequalities grew quickly in Estonia (Lindemann, Saar 2012), peaking in the year 2000, but have decreased since then due to the introduction of more generous welfare measures in comparison to the previous decade (Tammaru et al. 2015a). 95 percent of housing became privately owned by the end of the 1990s (Hegedüs, Lux, Teller, eds. 2013), while properties returned to previous owners through restitution formed about three percent of the housing stock in Tallinn (Kährik, Kõre 2013); rent regulation in the restituted housing sector lasted until 2004 (Lux, Kährik, Sunega 2012).

Both cities, Prague and Tallinn, are important capital cities in their respective countries with historical inner city housing structures. Due to economic regression in the $1990 \mathrm{~s}$, residential mobility remained low in Tallinn until the 2000 s, whereas in Prague, despite the more regulated housing sector, significant redistributions already began in the 1990s (Marcinćzak et al. 2015). The stronger economic and financial climate during a large part of the 2000s intensified residential changes in both cities. Quicker liberalisation of the restituted housing sector could be expected to have an impact on more radical population change and physical upgrade in the historical housing in Tallinn. In Prague, the change has largely triggered the displacement of the Roma population.

\subsection{Inner city neighbourhoods in Tallinn}

Tallinn is divided into eight administrative districts. In this study, the inner city is constrained to three districts, namely, Central Tallinn, North Tallinn, and Kristiine (Fig. 1). This delimitation is applied in response to the limitations 


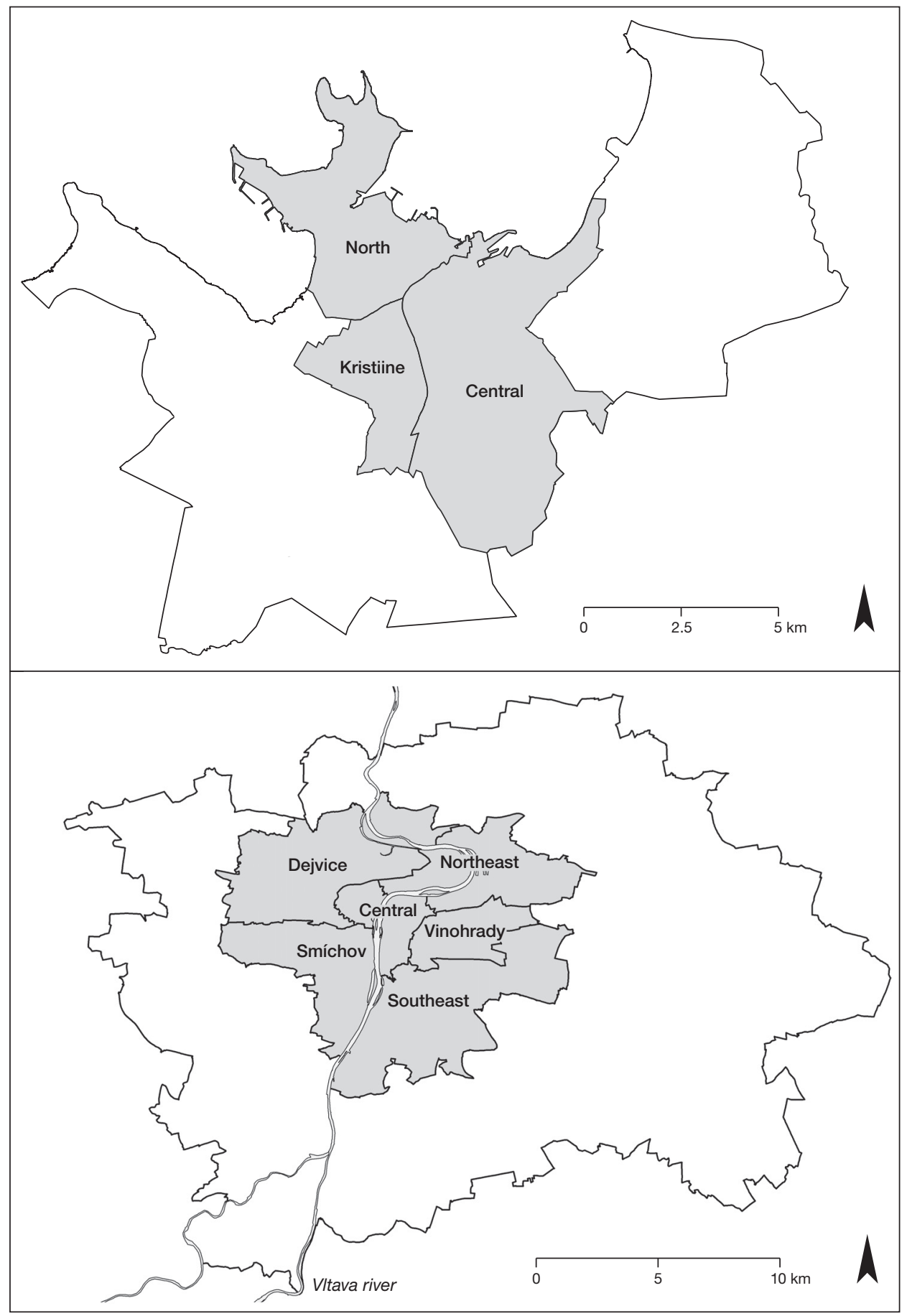

Fig. 1 - Inner cities of Tallinn (top) and Prague (bottom). Source: Estonian statistical office and Czech statistical office (2012). 
of administrative city divisions and available statistics. Although it includes the central city with the city's commercial and cultural core (for comparative reasons the same applies also in the case of Prague), it largely corresponds to the broad definition of the inner city as given in the introduction. One third of the 400,000 inhabitants of Tallinn lived in the inner city in 2000 according to such a definition. North Tallinn is the most exposed to the Baltic Sea, being situated on a narrow peninsula, and this is an area of $19^{\text {th }}$ to early $20^{\text {th }}$-century industrialisation that also remained highly industrialised during the Soviet period. The other two inner city districts have a less industrial past: Central Tallinn has the densest housing, including historical quarters from Medieval times, but also those from the $19^{\text {th }}$ to early $20^{\text {th }}$-century, infills from the socialist and post-socialist periods, various commercial facilities and diverse urban infrastructure, while Kristiine has a diversity of housing types, including historical housing, as well as prefabricated blocks of flats from the Soviet period and some later infills.

The degree of socio-economic residential differentiation, as measured by occupational categories, was low across neighbourhoods in Tallinn at the end of the socialist period (Raitviir 1990). Nonetheless, a high proportion of administrative employees lived in the Stalinist era apartments (built in the 1950s) in Central Tallinn. North Tallinn and Kristiine were more polarised, since industrial workers and higher social status administrative employees were over-represented (the latter group lived in prefabricated blocks of flats; whereas the former mostly lived in deteriorating pre-WW II housing stock close to the factories; Raitviir 1990). As mentioned, the low level of residential mobility greatly restricted inner city residential change before 2000 . Therefore, census data from 2000 reveals no major age or educational differences between inner city residents and the rest of the city. The inner city does however have a slight over-representation of elderly people (70+) and households without children, especially in Central Tallinn. In the whole inner city there were no educational differences with the rest of the city, but the educational level differed substantially between inner city districts, with Central Tallinn having the highest education (28\% with tertiary education) and North Tallinn with the lowest education (15\% having tertiary education). The study by Tammaru et al. (2015) shows that high-status groups during the 2000s have expanded their presence in many inner city neighbourhoods in Central Tallinn and North Tallinn, whereas Kristiine has remained largely mixed.

\subsection{Inner city neighbourhoods in Prague}

The inner city of Prague is heterogeneous both morphologically and with regard to housing types. In order to better correspond to the inner city definition as set in the Introduction, we followed Ouředníček et al. (2012) in defining the inner city ${ }^{1}$ (Fig. 1). Based on this definition and the analysis of the 1991

1 Due to the different structure of available EU-SILC dataset for Prague, it became possible to delimit the inner city independently of administrative city district divisions; it was not possible in the case of Tallinn. 
census data ${ }^{2}, 46$ percent of the 1.2 million inhabitants of Prague lived in the inner city at that time. We have also subdivided the inner city into six districts, namely, Central district, Vinohrady, Southeast, Smichov, Dejvice, and Northeast, based on their housing and urban landscape features rather than their administrative borders. Some of the most prestigious neighbourhoods are located on the hills that rise above the banks of the Vltava River (e.g., parts of the Dejvice, Smíchov, and Southeast districts). The housing composition of Prague's inner city is characterised by the mix of the $19^{\text {th }}$ to early $20^{\text {th }}$-century tenement houses, villa neighbourhoods from the early $20^{\text {th }}$ century, some of the city's oldest socialist housing estates built during the 1950s and 1960s, and new housing developments constructed in the past 20 years. The abovedescribed mix of residential landscapes applies to all six of the studied inner city districts, which therefore allows only a very rough generalisation of their characteristics. However, the districts have the following distinctive features: the Central district represents the city's commercial and cultural core, Vinohrady accommodates some of the better-quality pre-WWII tenement housing, Northeast mainly consists of working-class dwellings, Dejvice is characterised by prestigious villas and tenement housing, and Smíchov and Southeast contain a mix of tenement housing and villa neighbourhoods.

As is revealed in the 1991 census, ageing was a characteristic feature of inner city development in Prague at the end of the socialist period - to a much higher extent than in the case of Tallinn. Namely, 45 percent of the inner city population consisted of persons aged 50 and over (31\% in the rest of the city); the high share of elderly people was typical of all inner city districts. Also, the university graduates were slightly over-represented in the inner city in 1991, especially in the Central district and prestigious Dejvice district, while traditional working class districts in the Northeast stood as having the lowest education rate. Since the 1990s, gradual regeneration has been apparent in many inner city neighbourhoods (Temelová 2007); the Central district of Prague has become a sought-after business location and popular tourist destination.

\section{Data and methods}

Our research is based on data derived from the European Union Statistics on Income and Living Conditions (EU-SILC) for Tallinn and Prague. These data are unique because they include precise information on household income, which allows us to provide explicit evidence on the socio-economic up and downgrading processes in the inner city. No such micro-level data are available in larger national datasets such as censuses that would otherwise be applied for more detailed spatial analyses. The EU-SILC dataset is therefore invaluable in shedding light on the socio-economic divisions in large city districts (the size of the sample did not allow for studying smaller area units). The data

21991 census data was available for Prague on intra-urban neighbourhood level, but this was not the case for Tallinn. However, using 2000 census data for Tallinn (instead of 1990) was considered adequate since residential changes only gained momentum in Tallinn in the 2000 s. 
collected for sampled households ${ }^{3}$ in 2007-2011 were pooled into one database to increase the sample size and facilitate our analysis. The sample size of this pooled dataset for Tallinn was 4,153 households (1,355 respondents in the inner city) and 4,374 households (2,063 in the inner city) for Prague.

First, we conducted a binary logistic regression with the dependent variable being place of residence in the inner city (coded as 1) or elsewhere in the city (coded as 0 ). We then analysed the social differentiation in the studied inner cities by applying a number of multinomial logistic regression models. The dependent variable was categorised based on the district of residence (three in Tallinn and six in Prague) in order to examine the spatial patterns of inner city differentiation. In the next step, we developed two city-specific models in order to analyse specific drivers of social differentiation in inner cities. In Tallinn, we focused on the construction year of dwellings (dependent variable categories: living in a house built before 1946; built in 1946-1960; built in 1961-1991 ${ }^{4}$ ) since previous studies point to supply-side explanations of housing differentiation (Kährik, Tammaru 2010). In Prague, we focused on rent regulation (dependent variable categories: owner; renter in the regulated rental market; renter in the commercial rental market) since previous studies point to the importance of institutional mechanisms (rent regulation) in allowing lower-income households to continue to reside in the inner city (Ouředníček, Temelová 2009).

The EU-SILC provides a rich set of variables for analysis. In this study, however, we selected those key socio-demographic variables that are the most fundamental to an understanding of the features of the demographic and social landscape of inner cities. These variables are: age (15-34; 35-49; 50-69; 70+), gender, the presence of dependent children aged under 18 in the household, education level (primary, secondary, tertiary), and household income quartiles (for the distribution of the variables, see Table 1). Although education level and household income were correlated to some degree, our samples were sufficiently large and representative to avoid the problem of multicollinearity. The calculated VIF's for all the variables in our models did not exceed the value 1.20 (the critical value signalling multicollinearity is 2.5 ).

\title{
5. Results: patterns and drivers of inner city social differentiation in Prague and Tallinn
}

\author{
5.1. Do inner cities differ from the rest \\ of the city environs in respect of social and \\ demographic composition?
}

Our first finding is in line with the first hypothesis. Our study shows that younger age groups were indeed more likely to reside in inner city Prague and Tallinn (Table 1 and 2). The noticeable prevalence of young households

3 We have used data for the head of households.

4 The number of respondents who lived in the post-1991 buildings was insufficient for the purposes of our analyses. 
Table 1 - Main characteristics of the research population (\%)

\begin{tabular}{|c|c|c|c|c|}
\hline & TAI & INN & PR & UE \\
\hline & Inner city & Elsewhere & Inner city & Elsewhere \\
\hline Age group & & & & \\
\hline $15-34$ & 26 & 21 & 17 & 16 \\
\hline $35-49$ & 27 & 29 & 20 & 24 \\
\hline $50-69$ & 29 & 33 & 37 & 40 \\
\hline $70+$ & 18 & 18 & 27 & 20 \\
\hline Gender & & & & \\
\hline Male & 51 & 55 & 68 & 73 \\
\hline Female & 49 & 45 & 32 & 27 \\
\hline Dependent & & & & \\
\hline No & 65 & 62 & 78 & 69 \\
\hline Yes & 35 & 38 & 22 & 31 \\
\hline Education 1 & & & & \\
\hline Primary & 11 & 9 & 6 & 4 \\
\hline Secondary & 47 & 48 & 62 & 70 \\
\hline Tertiary & 43 & 43 & 32 & 26 \\
\hline Household & & & & \\
\hline $1^{\text {st }}$ & 26 & 24 & 26 & 24 \\
\hline $2^{\text {nd }}$ & 22 & 26 & 25 & 25 \\
\hline $3^{\text {rd }}$ & 25 & 25 & 23 & 27 \\
\hline $4^{\text {th }}$ & 27 & 25 & 26 & 24 \\
\hline $\mathrm{N}$ & 478 & 1,068 & 2,063 & 2,311 \\
\hline
\end{tabular}

Source: EU-SILC 2007-2011

reflects the growing attractiveness of inner city living among young people, including many "transitory" residents. Nevertheless, an important difference characterises Prague and Tallinn: in contrast to Tallinn where a generational shift seemingly takes place, both the oldest and youngest age groups were likely to reside in the inner city of Prague to a similar degree. The ongoing demographic ageing together with the long-lasting rent regulation in the sector of pre-WWII housing provide explanations as to the numbers of elderly people residing in Prague inner city. The in-depth study by Temelová and Dvořáková (2012) shows that the increased liveliness and rising cost of living have not led to a decline of desirability of inner city living for older people. In Tallinn, on the other hand, the rapid rent increases and selling off of dwellings in the private restituted sector have had an impact on displacements, i.e., pushing out elderly people with lower level of socio-economic resources towards outer urban or suburban zones. However, ageing was also less of a problem in Tallinn inner city (as compared to Prague) at the end of the socialist period.

Interestingly, in both Tallinn and Prague, more female residents were found in the inner city, which concurs with the findings of studies on migration and urbanisation suggesting that urban life as such attracts more women (e.g., Boyle, Halfacree, eds. 1999), but the over-representation of female households 
Table 2 - Results of the binary logistic regression on the correlates of living in the inner city versus living elsewhere, odds ratios

\begin{tabular}{|lcc|}
\hline & TALLINN & PRAGUE \\
\hline Age group (ref=50-69) & & \\
$15-34$ & $1.49^{* * *}$ & $1.24^{* *}$ \\
$35-49$ & 1.15 & 1.08 \\
$70+$ & 0.98 & $1.40^{* * *}$ \\
\hline Gender (ref=female) & & \\
Male & $0.88^{*}$ & $0.81^{* *}$ \\
\hline Dependent children (ref=yes) & & \\
No & $1.21^{* *}$ & $1.55^{* * *}$ \\
\hline Education level (ref= secondary) & & \\
Primary & 1.16 & $1.81^{* * *}$ \\
Tertiary & 1.05 & $1.43^{* * *}$ \\
\hline Household income quartile $\left(\right.$ ref $\left.=2^{\text {nd }}\right)$ & & \\
$1^{\text {st }}$ & $1.26^{* *}$ & 0.90 \\
$3^{\text {rd }}$ & 1.09 & 0.90 \\
$4^{\text {th }}$ & 1.14 & 1.15 \\
\hline
\end{tabular}

Significance levels: *** 1\%; ** 5\%; *10\%

Source: EU-SILC 2007-2011

might also be explained by the higher life expectancy of women. In accordance with the previous studies in the East and West, there is also the tendency for inner cities to attract households without children who are often transitory residents (Haase, Grossmann, Steinführer 2012; Feijten, Mulder 2002; Kährik et al. 2015; Karsten 2003), or elderly one-person female households (as in Prague).

Our second hypothesis suggested that there is a greater socio-economic differentiation in the inner city of Tallinn, compared to Prague, due to a greater degree of neoliberalisation. As it appears from the analyses, the correlation between free markets and raising socio-spatial inequalities is yet not that straightforward. Educational polarisation was visible among inner city residents of Prague (both primary and tertiary-educated inhabitants were more likely to be present); nevertheless, based on census data from 1991, a slightly higher educational status characterised inner city of Prague by the end of the socialist era. By contrast, all educational groups had equal chances to be present in the inner city of Tallinn as a whole. As to income differences, the findings imply that educational attainment rather than household wealth explains living in the inner city of Prague, which could be the outcome of a relatively egalitarian society in Czechia (Večerník 1996), as well as long-lasting rent regulation. In Tallinn, somewhat contrary to our expectations in assuming that neoliberal trends lead to the quick displacement of low income groups in attractive inner city areas, our results showed that in the second half of the 2000s, the lowest income earners continued to be the most likely groups to live in the inner city. Despite the greater social inequalities in Estonia and shorter duration of rent 
regulation in comparison to Prague, the evidence of lower-income households being forced out of the inner city of Tallinn is therefore sparse. Since many of the tenement houses in inner Tallinn are still wood-heated, they tend to be relatively cheap to live in, when compared, for instance, to apartments in large housing estates that have higher utility costs (Kährik, Tammaru 2010). However, in order to test our assumption about certain housing segments in the inner city attracting lower-income households, we next examine the differences in inner city sub-areas, as well as housing (tenure) types in inner city Tallinn and Prague.

\subsection{Spatial patterns of population differentiation in inner cities}

Significant differences existed in population composition (i.e., households with different social and demographic backgrounds) between the sub-districts of inner city Tallinn and Prague. Spatial differences existed in terms of the age and type of households. In Tallinn, younger age groups (especially those in the 15-34 year old bracket) and households without dependent children were only over-represented in Central Tallinn (Table 3) - the area with the most distinctive urban environment with dense building structures, concentration of social and public infrastructure, and office spaces. As the effect of socialist legacies, people aged 70 and over were more likely to live in Central Tallinn as well. Hence, despite the shorter duration of rent regulations and higher degree of market conditions, older people have not been overly pushed out from the central district. They continue to stay attached to their long-term place of residence - the situation facilitated by the give-away privatisation process.

In the case of inner city Tallinn as a whole, the age of housing stock also plays an important role in age distribution (Table 4) - namely, younger age groups (especially 15-34, year olds but also 35-49 year olds) were more likely to be attracted to older, i.e., pre-1946 and 1946-1960 housing stock ${ }^{5}$, and rental housing (the model available upon request). Of such flats, many are more affordable, cheaper rental substandard flats, which have become sought after to so-called first generation gentrifiers (gentrification "pioneers"), i.e., students and young non-family households ${ }^{6}$.

In the case of Prague, while the polarisation of age structure is characteristic of the whole inner city, the district-level variation is remarkable, and gives a somewhat different picture (Table 3). Namely, younger age groups and older groups tend to be segregated into different parts of the inner city, i.e., younger groups in Northeast and elderly in Southeast, Smichov, Dejvice and Southeast, while Vinohrady is the only district that has a polarised structure. Families

5 In total, $51 \%$ of the population of inner city Tallinn lives in houses built during 1961-1991, followed by 25 percent living in pre-1946 houses; 18 percent lives in houses built during the Stalin period (1946-1960), and 6 percent in post-1991 housing stock.

6 Previous studies refer to a declining prestige and social decline in the large Soviet-era housing estates, and increasing preference for smaller scale housing and/or communitybased lifestyles that certain inner city neighbourhoods can provide (Tammaru et al. 2015, Kährik et al. 2015). 
Table 3 - Results of the multinomial logistic regression on the correlates of living in different parts of the inner cities of Tallinn and Prague (reference category: elsewhere), odds ratios

\begin{tabular}{|c|c|c|c|c|c|c|c|c|c|}
\hline & \multicolumn{3}{|c|}{ TALLINN } & \multicolumn{6}{|c|}{ PRAGUE } \\
\hline & Central & Kristiine & North & Central & Vinohrady & Southeast & Smíchov & Dejvice & Northeast \\
\hline \multicolumn{10}{|c|}{ Age group (ref $=50-69)$} \\
\hline $15-34$ & $3.53^{* * *}$ & 1.18 & 1.02 & 0.89 & $2.00 * * *$ & 1.10 & 0.93 & 1.18 & $1.49 * *$ \\
\hline $35-49$ & $2.10 * * *$ & 0.99 & 0.92 & 0.99 & $1.45^{*}$ & 0.95 & 0.92 & 0.91 & $1.48 * *$ \\
\hline $70+$ & $1.84 * * *$ & 0.81 & 0.82 & 1.10 & $1.42^{*}$ & $1.81^{* * *}$ & $1.44^{* *}$ & $1.42^{* *}$ & 1.00 \\
\hline \multicolumn{10}{|c|}{ Gender (ref $=$ female $)$} \\
\hline Male & 0.92 & $0.70 *$ & 0.99 & $0.52^{* * *}$ & $0.69 * *$ & 0.98 & 1.12 & $0.71 * *$ & $0.79 *$ \\
\hline \multicolumn{10}{|c|}{ Dependent children (ref $=$ yes) } \\
\hline No & $1.75^{* * * *}$ & 0.88 & 1.16 & $2.07 * * *$ & $1.59 * *$ & 1.13 & $2.06 * * *$ & $1.62^{* *}$ & $1.60 * *$ \\
\hline \multicolumn{10}{|c|}{ Education level (ref = secondary) } \\
\hline Primary & 1.04 & $0.54 * *$ & $1.50 * * *$ & 1.31 & $2.91 * * *$ & $1.62^{* *}$ & $2.62^{* * * *}$ & 0.55 & $2.33^{* * *}$ \\
\hline Tertiary & $1.60 * * *$ & 1.08 & $0.78 * *$ & $2.55 * * *$ & $1.36^{*}$ & $1.45^{* *}$ & 0.97 & $1.98^{* *}$ & 0.82 \\
\hline \multicolumn{10}{|c|}{ Household income quartile $\left(\mathrm{ref}=2^{\text {nd }}\right)$} \\
\hline $1^{\text {st }}$ & $1.57 * *$ & 0.97 & $1.27 *$ & 0.92 & 0.87 & 1.11 & $0.56^{* *}$ & 0.84 & 0.91 \\
\hline $3^{\text {rd }}$ & 1.13 & 1.16 & 1.04 & 0.92 & 0.96 & 0.84 & 0.92 & 0.97 & 0.87 \\
\hline $4^{\text {th }}$ & $1.71^{* * *}$ & 1.33 & $0.75 * *$ & $1.47^{*}$ & 1.04 & 0.93 & $1.48^{* *}$ & 1.20 & 1.13 \\
\hline
\end{tabular}

Significance levels: *** $1 \%$; * $5 \%$; $10 \%$

Source: EU-SILC 2007-2011

(aged 35-49) mostly tend to live in Northeast and Vinohrady. It is further noteworthy that several differences mark Central Prague as compared to Central Tallinn - no polarisation of the age structure was found, while there was a strong over-representation of females and households without children. While the over-representation of childless households was common to most of the inner city districts of Prague, in Tallinn it was only the case in Central Tallinn.

As in Tallinn, young households (especially 15-34 year olds but also 35-49 year olds) were more likely to be private tenants ${ }^{7}$ in Prague (Table 4) because to become an owner-occupier requires a stable income. Students and young childless couples at the beginning of their housing and working careers often have no choice but to rent a substandard flat in a less attractive inner city neighbourhood. Due to large-scale privatisation, older households are more often owner-occupiers, or long-term tenants in rent-regulated housing (rent regulation has protected the elderly from being driven out of attractive inner city areas).

Secondly, inner city differentiation by socio-economic characteristics also yields interesting results. Although we found no educational differentiation in inner Tallinn compared with the rest of the city, the differences do exist at district level (Table 3). Higher social status groups incline towards Central

7 In Prague, $48 \%$ of the inner city population were owner-occupiers, while $12 \%$ were private renters on the commercial market and the rest lived in rent-regulated apartments. 
Table 4 - Results of the multinomial logistic regression on the correlates of the age of housing (for Tallinn) and tenure (for Prague) in the inner city of Tallinn and Prague (reference category: elsewhere), odds ratios.

\begin{tabular}{|c|c|c|c|c|c|c|}
\hline & & TALLINN & & & PRAGUE & \\
\hline & $\begin{array}{c}\text { Before } \\
1946\end{array}$ & $1946-1960$ & 1961-1991 & $\begin{array}{l}\text { Owner- } \\
\text { occupied }\end{array}$ & $\begin{array}{l}\text { Regulat- } \\
\text { ed rent }\end{array}$ & $\begin{array}{l}\text { Commer- } \\
\text { cial rent }\end{array}$ \\
\hline Age group & & & & & & \\
\hline $15-34$ & $2.15^{* * *}$ & $2.49 * * *$ & 0.84 & $0.72^{* * *}$ & 1.14 & $5.39^{* * *}$ \\
\hline $35-49$ & $1.34^{*}$ & $1.74 * * *$ & 0.86 & 0.86 & 1.03 & $2.96^{* * *}$ \\
\hline $70+$ & 1.07 & 0.97 & 1.01 & $1.67 * * *$ & $1.29 * *$ & $0.61^{*}$ \\
\hline Gender (r & & & & & & \\
\hline Male & 1.21 & 0.96 & 0.78 & $0.82 * *$ & $0.80 * *$ & $0.74^{*}$ \\
\hline Dependen & ef = yes $)$ & & & & & \\
\hline No & 1.19 & $1.40 * *$ & $1.20 *$ & $1.20 *$ & $1.61 * * *$ & $2.97 * * *$ \\
\hline Education & secondary) & & & & & \\
\hline Primary & 0.93 & 0.96 & $1.39 * *$ & 0.77 & $3.06^{* * * *}$ & $1.82 *$ \\
\hline Tertiary & 1.04 & $1.38^{* *}$ & 1.91 & $1.75^{* * *}$ & $1.24^{* *}$ & 0.92 \\
\hline Househol & artile (ref = & $\left.=2^{\text {nd }}\right)$ & & & & \\
\hline $1^{\text {st }}$ & $1.64 * * *$ & $1.90 * * *$ & 0.92 & 0.92 & 0.90 & 0.81 \\
\hline $3^{\text {rd }}$ & $1.34^{*}$ & 0.84 & 1.13 & 0.90 & 0.90 & 0.95 \\
\hline $4^{\text {th }}$ & 1.24 & 1.09 & 1.04 & 1.14 & 1.06 & $1.43^{*}$ \\
\hline
\end{tabular}

Significance levels: $* * * 1 \% ; * * 5 \% ; * 10 \%$

Source: EU-SILC 2007-2011

Tallinn, while those that have a low education are more likely to live in North Tallinn - a district with many neighbourhoods with a lower state of repair as compared to Central Tallinn (so called "workers" housing), where cheaper housing options are available. Moreover, we also found signs of income differentiation in Tallinn (Table 3), which more or less followed the prescribed pattern of educational differentiation (only Central Tallinn portrays a polarised income pattern). To a large extent, however, such social status differentiation resembles socio-spatial patterns inherited from the socialist period, and also corresponds to distinctive physical layers of housing structures. The pattern can less be explained by dramatic shifts and the reversal of prestige and social status areas in Tallinn during the 2000s. The university graduates were more likely to live in Stalin-era buildings, while those with primary education were more often found in large prefabricated houses built during 1961-1991. Lowincome groups were likely to be found in either pre-1946 tenement houses the cheapest housing stock available in Tallinn - or in Stalin-era buildings. Interesting as well is the fact that the ongoing income polarisation tendencies are most noticeable in the pre-1946 tenement houses. The more dramatic generational displacement in the old pre-WW II housing was initiated by the restitution and rent deregulation processes.

Socio-economic differentiation was also found between the inner city districts of Prague (Table 3). The districts with the polarised character as regards 
educational attainment were Vinohrady and Southeast. Primary-educated people were more likely to reside in the traditional working-class districts of Smíchov and Northeast, while more highly educated inhabitants lived more often in the high-status villa quarters of Dejvice as well as in commercially and residentially sought-after Central Prague. Neither the spatial income differences nor the differences between the three housing tenure segments showed very significant income differentiation. Central Prague and Smichov were the two districts where the highest income groups are more likely to be found. Private rental dwellings tended to attract lower educated groups (however, they need to have sufficient financial resources) (Table 4). This rejects the view that the commercial rental sector attracts mainly gentrifiers and urban professionals. Dwellings that are substandard and cheaper could, however, be the potential targets of gentrifiers and developers in the future, next to high-quality luxury quarters. Similar to Tallinn, lower social status (by education) transitory groups penetrate the inner city housing market in Prague, particularly through the private rental market, but the long-regulated rental sector also served to keep the low educated in the inner city (however, the social structure in this sector was polarised).

In line with our third hypothesis, the income differentiation between inner city districts was, therefore, indeed more noticeable in Tallinn, whereas the educational differences applied to both inner cities to a comparable degree - the latter being explained by historical legacies rather than transformational shifts in urban social structures.

\section{Discussion and conclusions}

The systemic economic and housing market changes of the 1990s and 2000s have created a new context for inner city change in the post-socialist cities of Eastern Europe. According to the existing literature, the gradual transition to market conditions that occurred in various speeds across the region and increased socio-economic inequalities has facilitated reverse processes in inner cities in comparison to formerly existing residential trends during the socialist past. Namely, higher social status groups have started to move into areas previously over-represented by low-status groups and the elderly (e.g., Sýkora 2009). But authors have also referred to continuous evidence of local social mixing and "hybridisation" (e.g., Golubchikov, Badyina, Makhrova 2014). The results of applied comparative studies provided quantitative evidence on the character of population change in Eastern European inner cities.

Consistent with the findings presented by other studies (Buzar et al. 2007; Steinführer, Haase 2007; Haase et al. 2011; Kährik et al. 2015), the results described herein confirmed the preference for inner city living among young people and childless households, and pointed to the rejuvenation process of inner cities. Rejuvenation could even be regarded as the most apparent process reversing population trends in inner cities - the areas that were previously characterised by ageing populations. The dominance of "non-family" households has also been a general feature of inner city development in market-led housing systems since the living environment is considered to be less conducive 
to raising children (Rossi 1955). However, as our study showed, the housing policies and level of regulation plays a role - in Prague, the elderly still have more chances to reside in many of the inner city districts while age polarisation is characteristic to the inner city as a whole there; in Tallinn, rejuvenation and displacement of the elderly seem to be stronger processes than in Prague. However, due to the large-scale privatisation, many socialist socio-spatial structures, such as the continuous presence of the elderly in Central Tallinn, are being reproduced. Therefore, different generations reside side by side with each other. The privatisation practices allowed a sizable long-term population to stay in their present housing, whereas the long-lasting regulations in restituted housing enabled more elderly (sedentary population) to stay on (cf., Ouředníček, Temelová 2009). The choices of young people in Tallinn are also driven by the type of built environment, namely, pre-WWII and 1946-60 dwellings, which confirms the existence of a pattern of gentrification based on housing choice. Nevertheless, for younger age groups (up to the age of 34), this housing choice does not necessarily correspond with high income or education levels.

The gradual displacement of the elderly by young, often non-family, households has not, therefore, directly led to a social (educational, income) upgrade in the two inner cities. In Tallinn, where income divides have been raising most sharply, lower income groups were found to be still over-represented in the inner city, whereas the educational differences were not found in the inner city as a whole. Inner cities continued to be relatively mixed in the late $2000 \mathrm{~s}$, and inner city periphery was still in social decline, which was counter to our expectations that market mechanisms would have a stronger influence on spatial patterns. Central Tallinn alone showed some signs of income polarisation, which is indicative of simultaneous socio-economic up and downgrading processes. In Prague's inner city, we found no such income differentiation; instead, significant educational divides were evident. Here, educational capital has been and remains an important determinant of living standards, particularly in villa neighbourhoods and in the historical core of Prague. Not concluding that the mobility to inner city by upper income groups has not taken place in both cities, especially to central areas, these flows have, however, not been as wide-scale as to be able to lift the income status of Prague and Tallinn inner city to a noticeably higher position as compared to the outer cities.

The preservation of socialist legacies due to long-lasting regulations in restituted housing sector (in Tallinn until 2004, in Prague, until 2012) and privatisation practices on the one hand, and relatively low physical state housing stock with low prestige of many inner city neighbourhoods on the other hand, could be seen as explanations to why quick housing and social reforms (especially in Tallinn) have not brought along as dramatic transformations in the intra-urban geography of cities as could have been expected based on available literature. Inner cities have instead been discovered by young people who are still not high up in either an academic or income career (corresponding to the "first wave of gentrifiers" according to the gentrification theory); and only when the prestige and perception of inner city housing improves, then more diverse groups (families, middle and upper income groups) could be expected to be attracted by inner cities to a greater extent. Only a few districts, which already tended to have a higher prestige and social status during the 
socialist era, have continuously and increasingly attracted higher social status groups. From these neighbourhoods, high status slowly and gradually radiates outwards to raise the status of neighbouring areas. For example, the study by Tammaru (et al. 2015a) concludes that high-status groups, as measured by occupation, have expanded their presence in many neighbourhoods in Northern Tallinn, as well as in some areas adjacent to the city centre in the South and East that had been in social and physical decline during the Soviet period.

Finally, however, the methodological limitations of the study (EU_SILC) must be emphasised. The available data did not allow us to investigate smaller spatial units, which we might expect to show greater income-related variations. In particular, the housing structures in Prague's districts are heterogeneous and its smaller neighbourhoods differ considerably, but the type of data available may have concealed the existence of small-scale fragmentations and down or upgrading tendencies. Therefore, combining the results of this study with other sources of information is a necessity. Since no other data on population income is currently available, one of the possible research avenues is for indepth qualitative surveys not only to overcome the above-mentioned limitation but also to better understand the dynamics of emerging wealth and poverty pockets in inner cities.

We are grateful to the anonymous reviewers for their very valuable comments on our manuscript.

\section{In Memoriam}

This paper is dedicated to the memory of our co-authors Jakub Novák and Jana Temelová who recently passed away in a tragic car accident. We lost our good colleagues and wonderful friends, and Czech urban geography lost two of its brightest scholars.

\section{References:}

BADYINA, A., GOLUBCHIKOV, O. (2005): Gentrification in central Moscow - a market process or a deliberate policy? Money, power and people in housing regeneration in Ostozhenka. Geografiska Annaler, 87B, 2, pp. 113-129.

BEAUREGARD, R.A. (1990): Trajectories of neighbourhood change: the case of gentrification. Environment and planning A, 22, No. 7, pp. 855-874.

BERNT, M., HOLM, A. (2005): Exploring the substance and style of gentrification: Berlin's "Prenzlberg". In: Atkinson, R., Bridge, G. (eds.): Gentrification in a global context: the new urban colonialism. Routledge, Abingdon, New York, pp. 106-120.

BOSTIC, R.W., MARTIN, R.W. (2003): Black home-owners as a gentrifying force? Neighbourhood dynamics in the context of minority home-ownership. Urban Studies, 40, No. 12, pp. 2427-2449.

BOTERMAN, W., KARSTEN, L., MUSTERD, S. (2010): Gentrifiers settling down? Patterns and trends of residential location of middle-class families in Amsterdam. Housing Studies, 25, No. 5, pp. 693-714.

BOYLE, P.J., HALFACREE, K., eds. (1999): Migration and Gender in the Developed World. Routledge, London, $91 \mathrm{pp}$.

BUTLER, T., LEES, L. (2006): Super-gentrification in Barnsbury, London: globalization and gentrifying global elites at the neighbourhood level. Transactions of the Institute of British Geographers, 31, No. 4, pp. 467-487. 
BUZAR, S., OGDEN, P., HALL, R., HAASE, A., KABISCH, S., STEINFÜHRER, A. (2007): Splintering urban populations: Emergent landscapes of reurbanisation in four European cities. Urban Studies, 44, No. 4, pp. 651-677.

ENYEDI, G. (1998): Transformation in Central European post-socialist cities. In: Enyedi, G. (ed.): Social change and urban restructuring in Central Europe. Akademiai Kiado, Budapest, pp. 9-34.

FEIJTEN, P., MULDER, C.H. (2002): The timing of household events and housing events in the Netherlands: A longitudinal perspective. Housing Studies, 17, No. 5, pp. 773-792.

FELDMAN, M. (2000): Urban waterfront regeneration and local governance in Tallinn. Europe-Asia Studies, 52, No. 5, pp. 829-850.

FÖLDI, Z. (2008): Neighbourhood Dynamics in Inner-Budapest - a Realist Approach. Tijdschrift voor Economische en Sociale Geografie, 99, No. 2, pp. 262-264.

GOLUBCHIKOV, O., BADYINA, A. and MAKHROVA, A. (2014): The hybrid spatialities of transition: capitalism, legacy and uneven urban economic restructuring. Urban Studies, 51, No. 4, pp. 617-633.

HAASE, A., KABISCH, S., STEINFÜHRER, A., BOUZAROVSKI, S., HALL, R., OGDEN, P. (2010): Emergent spaces of reurbanisation: exploring the demographic dimension of inner-city residential change in a European setting. Population, Space and Place, 16, No. 5, pp. 443-463.

HAASE, A., GROSSMANN, K. and STEINFÜHRER, A. (2012): Transitory urbanites: New actors of residential change in Polish and Czech inner cities. Cities, 29, No. 5, pp. 318-326.

HAASE, A., STEINFÜHRER, A., KABISCH, S., GROSSMANN, K., HALL, R., eds. (2011): Residential Change and Demographic Challenge: The Inner City of East Central Europe in the $21^{\text {st }}$ Century. Ashgate, Farnham, $376 \mathrm{pp}$.

HEGEDÜS, J., M. LUX, N., TELLER, eds. (2013): Social housing in transition countries. Routledge, New York, London, $374 \mathrm{pp}$.

KARSTEN, L. (2003): Family gentrifiers: challenging the city as a place simultaneously to build a career and to raise children. Urban Studies, 40, No. 12, pp. 2573-2584.

KAZEPOV, Y., ed. (2004): Cities of Europe: Changing contexts, local arrangements and the challenge to social cohesion. Wiley-Blackwell, Oxford, $368 \mathrm{pp}$.

KÄHRIK, A.T., TAMMARU. T. (2010): Soviet prefabricated panel housing estates: areas of continued social mix or decline? The case of Tallinn. Housing Studies 25, No. 2, pp. 201-219.

KÄHRIK, A., TEMELOVÁ, J., KADARIK, K. and KUBEŠ, J. (2015): What attracts people to inner city areas? The cases of two post-socialist cities in Estonia and Czech Republic. Urban Studies, doi:10.1177/0042098014567444.

KÄHRIK, A., KÕRE, J. (2013): Social housing in Estonia after transition: in between the residual of privatization and the new developments. In: Hegedüs, J., Lux, M., Teller, N. (eds.): Social housing in transition countries: Trends, impacts and policies. Routledge Taylor \& Francis Ltd, New York, pp. 163-179.

KOVẢCS, Z. (2009): Social and economic transformation of historical neighbourhoods in Budapest. Tijdschrift voor economische en sociale geografie, 100, No. 4, pp. 399-416.

LEY, D. (1996): The New Middle Class and the Remaking of the Central City. Oxford University Press, Oxford, $383 \mathrm{pp}$.

LINDEMANN, K., SAAR, E. (2012): Ethnic inequalities in education: second-generation Russians in Estonia. Ethnic and Racial Studies, 35, No. 11, pp. 1974-1998.

LUX, M., KÄHRIK, A., SUNEGA, P. (2012) Housing restitution and privatization: both catalysts and obstacles to the formation of private rental housing in the Czech Republic and Estonia. International Journal of Housing Policy, 12, No. 2, pp. 137-158.

MARCIŃCZAK, S., TAMMARU, T., NOVÁK, J., GENTILE, M., KOVÁCS, Z., TEMELOVÁ, J., VALATKA, V., KÄHRIK, A., SZABÓ, B. (2015): Patterns of socioeconomic segregation in the capital cities of fast-track reforming postsocialist countries. Annals of the Association of American Geographers, 105, No. 1, pp. 183-202.

OUŘEDNÍČEK, M., TEMELOVÁ, J. (2009): Twenty years after socialism: the transformation of Prague's inner structure. Studia Universitatis Babes-Bolyai, Sociologia, 54, No. 1, pp. 9-30.

OUŘEDNÍČEK, M., POSPÍŠILOVÁ, L., ŠPAČKOVÁ, P., TEMELOVÁ, J., NOVÁK, J. (2012): Prostorová typologie a zonace Prahy. In: Ouředníček, M., Temelová, J. (eds.): Sociální proměny pražských čtvrtí. Academia, Praha, pp. 268-297. 
RAITVIIR, T. (1990): Linna sisestruktuurid. Faktorökoloogiline lähendus. Tallinna Linnauurimuse Instituut, Tallinn.

ROSSI, P.H. (1955): Why families move: a study in the social psychology of urban residential mobility. Free Press, Glencoe, IL.

SEO, J.K. (2002): Re-urbanisation in regenerated areas of Manchester and Glasgow. New residents and the problems of sustainability. Cities, 19, No. 2, pp. 113-121.

SMITH, D.M. (1996): The socialist city. In: Andrusz, G., Harloe, M., Szelényi, I. (eds): Cities after socialism. Urban and regional change and conflict in post-socialist societies. Blackwell, Oxford, pp. 70-99.

SMITH, D.P., HOLT, L. (2007): Studentification and “apprentice" gentrifiers within Britain's provincial towns and cities: extending the meaning of gentrification. Environment and Planning A, 39, No. 1, pp. 142-161.

STEINFÜHRER, A., HAASE, A. (2007): Demographic change as a future challenge for cities in East Central Europe. Geografiska Annaler, 89B, No. 2, pp. 183-195.

SZELÉNYI, I. (1996): Cities under socialism - and after. In: Andrusz, G., Harloe, M., Szelényi, I. (eds): Cities after socialism. Urban and regional change and conflict in post-socialist societies. Blackwell, Oxford, pp. 286-317.

SÝKORA, L. (2005): Gentrification in post-communist cities. In: Atkinson, R., Bridge, G. (eds.): Gentrification in a global context. Routledge, London, New York, pp. 90-105.

SÝKORA, L. (2009): Post-socialist cities. In: Kitchin, R., Thrift, N. (eds.): International encyclopedia of human geography, vol. 8. Elsevier, Oxford, pp. 387-395.

SÝKORA, L., BOUZAROVSKI, S. (2012): Multiple transformations: conceptualising postcommunist urban transition. Urban Studies 49, No. 1, pp. 43-60.

TAMMARU, T., KÄHRIK, A., MÄGI, K., NOVÁK, J., LEETMAA, K. (2015a): The "market experiment": Changes in socio-economic segregation in the inherited bi-ethnic context in Tallinn. In: Tammaru, T., Marcińczak, S., van Ham, M., Musterd, S. (eds.): East meets West: New perspectives on socio-economic segregation in European capital cities. Routledge, London.

TAMMARU, T., MUSTERD, S., VAN HAM, M., MARCIŃCZAK, S. (2015b): Inequality and socio-economic segregation: A multifactor framework for a comparative study of European capital cities. In: Tammaru, T., Marcińczak, S., van Ham, M., Musterd, S. (eds.): East meets West: New perspectives on socio-economic segregation in European capital cities. Routledge, London.

TEERNSTRA, A.B., VAN GENT, W.P.C. (2012): Puzzling patterns in neighbourhood change: upgrading and downgrading in highly regulated urban housing markets. Urban Geography, 33, No. 1, pp. 91-119.

TEMELOVÁ, J. (2007): Flagship developments and the physical upgrading of post-socialist inner city: the Golden Angel project in Prague. Geografiska Annaler, 89B, No. 2, pp. 169-181.

TEMELOVÁ, J., DVOŘÁKOVÁ, N. (2012): Residential satisfaction of elderly in the city centre: The case of revitalizing neighbourhoods in Prague. Cities, 29, No. 5, pp. 310-317.

TEMELOVÁ, J., NOVÁK, J. (2011) Daily street life in the inner city of Prague under transformation: the visual experience of socio-spatial differentiation and temporal rhythms. Visual Studies, 26, No. 3, pp. 213-228.

TEMELOVÁ, J., NOVÁK, J., OUŘEDNÍČEK, M., PULDOVÁ, P. (2011): Housing estates in the Czech Republic after socialism: various Trajectories and Inner Differentiation. Urban Studies, 48, No. 9, pp. 1811-1834.

VAN CRIEKINGEN, M., DECROLY, J-M. (2003): Revisiting the diversity of gentrification: neighbourhood renewal processes in Brussels and Montreal. Urban Studies, 40, No. 12, pp. 2451-2468.

VECERNÍK, J. (1996): Earnings disparities in the Czech Republic: the history of equalisation. Czech Sociological Review, 4, No. 2, pp. 211-222.

WORLD BANK (2002): Transition. The First Ten Years. Analysis and Lessons for Eastern Europe and the Former Soviet Union. The World Bank, Washington, DC, 128 pp.

ZUKIN, S. (1982): Loft Living: Culture and Capital in Urban Change. Johns Hopkins University Press, Baltimore, $237 \mathrm{pp}$. 


\section{MODELY A HYBNÉ SÍLY SOCIÁLNÍ DIFERENCIACE VNITŘNÍHO MĚSTA V PRAZE A TALLINNU}

Obytné oblasti vnitřních částí východoevropských měst, tedy obytná území mezi obchodním jádrem a vnějšími městskými zónami, charakterizovaná existencí před-socialistických sídelních vrstev, trpěly v průběhu socialisté éry velkým nedostatkem investic. Vnitřní města tak fyzicky i sociálně chátrala, a stala se primárně domovem pro stárnoucí městskou populaci. Systémové změny v ekonomice i trhu s bydlením, které proběhly v devadesátých letech a v prvním desetiletí nového století, vytvořily pro vývoj vnitřních měst nové prostředí. Existující literatura primárně poukazuje na to, že postupná transformace tržního systému, která proběhla v celém regionu nerovnoměrnou rychlostí, a nárůst socio-ekonomických nerovností, spustil ve vnitřních městech obrácené sídelní procesy. Skupiny s vyššími př́ijmy se začaly stěhovat do míst dříve obsazených nízkopřímovými skupinami, přestože se objevovaly i mnohé případy sociálního mísení. Na základě dat EU-SILC 2007-2011 jsme analyzovali procesy socio-prostorové diferenciace vnitřních měst Prahy v Česku a Tallinnu v Estonsku a pokusili jsme se identifikovat mechanismy této diferenciace na úrovni domácností. Výsledky této studie tak poskytly kvantitativní důkazy o povaze populačních změn ve vnitřních městech.

Výsledky výzkumu tak ukazují zejména na oblibu života ve vnitřním městě mezi mladými lidmi a bezdětnými domácnostmi a celkový proces obnovy ve vnitřních oblastech východoevropských měst. Omlazení je pravděpodobně nejvýraznějším populačním trendem ve vnitřních městech, kde dříve dominovala stárnoucí populace. Jak ovšem ukazuje naše studie, hrála v tomto ohledu významnou roli politika bydlení a úroveň regulací uplatňovaná v období transformace. V Praze byla úroveň regulace vyšší, proto má starší populace stále sklon koncentrovat se do některých čtvrtí vnitřního města, přičemž věková polarizace je typická pro celé město. V Tallinnu je omlazení města a odsun starších obyvatel mnohem zřetelnější, nicméně levná privatizace přesto zachovala v některých tallinnských oblastech koncentraci starších rezidentů. Ve východoevropských městech tak bydlí různé generace vesměs bok po boku. Způsob privatizace umožnil velké části populace zůstat ve svých stávajících domovech, přičemž tempo následných změn bylo $\mathrm{z}$ velké části určováno mírou regulace. V Praze se tak v některých místech zachovalo větší procento starších obyvatel. Volby mladých obyvatel Tallinnu z hlediska ubytování jsou primárně ovlivněny prostředím. Zájem je primárně o budovy postavené před druhou světovou válkou nebo mezi lety 1946-1960. Pro mladou generaci (do 34 let), ale tato volba úplně nekoresponduje s úrovní jejich příjmů či vzdělání. V Praze i v Tallinnu tak hrají důležitou roli v revitalizaci vnitřních měst i studenti či lidé na začátku svých pracovních kariér. Postupné vytlačování starších obyvatel mladými, často bezdětnými domácnostmi vedlo k sociálnímu zlepšení (ve smyslu vzdělání a příjmů) obou vnitřních měst. V Tallinnu, kde došlo $\mathrm{v}$ devadesátých letech $\mathrm{k}$ ostrému nárůstu přijmových nerovností, bylo vnitřní město stále disproporčně více obýváno nižšími př́íjmovými skupinami, ovšem rozdíly v úrovni vzdělanosti se ukázaly jako nepatrné. Obyvatelstvo vnitřního města bylo stále velmi smíšené i na konci první dekády nového tisíciletí. Periferie vnitřního města se dokonce ocitly v sociálním úpadku, což bylo v protikladu s naším očekáváním, že se rychlé spuštění tržních mechanismů výrazně projeví na prostorových vzorcích. Pouze vnitřní zóna Tallinnu vykázala výrazné známky př́ijmové polarizace. Ve vnitřním městě Prahy se př́ijmové rozdíly př́liš neprojevily, místo toho se ale ukázala jasná vzdělanostní diferenciace. Vzdělanostní kapitál je důležitým faktorem určujícím životní úroveň, zejména ve vilových čtvrtích či v historickém centru. To neznamená, že by pohyb lépe situovaných sociálních skupin do centra města (zejména do historického jádra) neprobíhal, nicméně tyto trendy nebyly dostatečně výrazné k tomu, aby vnitroměstské oblasti sociálně a ekonomicky viditelně pozvedly nad zbytek města.

Pozůstatky dědictví socialismu v podobě dlouho trvajících regulací obchodu s restituovanými nemovitostmi (v Tallinnu do roku 2004 a v Praze do roku 2012) a způsob privatizace na jedné straně a relativně špatný fyzický stav dostupných domů a nízká prestiž některých vnitroměstských lokalit na straně druhé způsobily, že rychlé reformy v sociálním sektoru a oblasti bydlení (zejména v Tallinnu) nepřinesly tak dramatickou změnu vnitroměstského 
prostoru, jak by se dalo očekávat na základě akademické literatury. Vnitřní města byla zatím znovuobjevena zejména mladými lidmi na počátcích pracovní či akademické kariéry, kteří se více blíží takzvaným aktérům gentrifikace první generace. Jen až se změní vnímání bydlení ve vnitřním městě, lze očekávat významnější příchod dalších skupin obyvatel (rodin, středně a vysoko př́jmových skupin). Pouze několik málo čtvrtí, které se již v období socialismu těšily dobré pověsti, dokázalo přilákat skupiny s vyšším společenským statusem. Z těchto oblastí se potom pozitivní vnímání a prestiž šírí dále do přilehlých oblastí.

Je třeba také vést v patrnosti omezení vycházející z využití samotné databáze EU_SILC. Shromážděné informace o př́ijmových nerovnostech nám nedovolily prozkoumat menší prostorové jednotky, kde by možná existovala větší příjmová diferenciace. Domovní výstavba v pražských čtvrtích je velmi heterogenní a jednotlivá sídliště se mohou výrazně lišit. Povaha analyzovaných dat nicméně skryla jejich možné fragmentace či specifické vývojové tendence. Je tedy nutné kombinovat výstupy této studie $\mathrm{s}$ informacemi získanými z jiných výstupů. Vzhledem k tomu, že nejsou k dispozici žádná další prostorová data o př́ijmových skupinách, nabízí se možnost hloubkového kvalitativního průzkumu, který by nejen pomohl překonat zmíněná omezení, ale také by dokázal lépe odhalit dynamiku vzniku enkláv bohatství či chudoby ve vnitroměstském prostoru.

Obr. 1 -Vnitřní město Tallinnu (nahoře) a Prahy (dole). Zdroj: Estonský statistický úřad a Český statistický úřad, 2012.

Authors'affiliation: A. Kährik: EU FP7 Marie Curie fellow at the Institute for Housing and Urban Research, Uppsala University, Uppsala, Sweden; University of Tartu, Institute for Ecology and Earth Sciences, Department of Geography, Tartu, Estonia; e-mail: Anneli.Kahrik@ut.ee. J. Novák, J. Temelová: Charles University in Prague, Faculty of Science, Department of Social Geography and Regional Development, Prague, Czechia. K. Kadarik: Uppsala University, The Institute for Housing and Urban Research, Uppsala, Sweden; University of Tartu, Institute for Ecology and Earth Sciences, Department of Geography, Tartu, Estonia; e-mail: Kati.Kadarik@ ut.ee. T. Tammaru: University of Tartu, Institute for Ecology and Earth Sciences, Department of Geography, Tartu, Estonia; e-mail: Tiit.Tammaru@ut.ee.

Initial submission, 2 July 2014; final acceptance 18 April 2015.

\section{Please cite this article as:}

KÄHRIK, A., NOVÁK, J., TEMELOVÁ, J., KADARIK, K., TAMMARU, T. (2015): Patterns and Drivers of Inner City Social Differentiation in Prague and Tallinn. Geografie, 120, No. 2, pp. 275-295. 